\title{
The Effect of Financial Distress, Firm Growth, and Previous Year's Opinion on the Firm's Going Concern Opinion
}

\author{
Amiruddin \\ \{amiruddin@fe.unhas.ac.id\}, Faculty of Economics and Business, Hasanuddin University, Makassar, Indonesia.
}

\section{Grace T. Pontoh}

\{gracetpontoh@fe.unhas.ac.id\}, Faculty of Economics and Business, Hasanuddin University, Makassar, Indonesia.

\author{
Marina Lauren \\ \{marinalauren25@gmail.com\}, Faculty of Economics and Business, Hasanuddin University, Makassar, Indonesia.
}

\begin{abstract}
This research aims to examine and determine the impact of financial distress, firm growth, and opinion on previous year to firms'going concern. The study was carried on service companies that are listed on Indonesia Stock Exchange during 2015-2017. A total of 210 samples were selected using the purposive sampling method. This research utilizes secondary data in the form of the firm's financial statements and independent auditor's reports. This research utilized logistic regression analysis to process the data. Results showed that financial distress and previous year's opinion has significantly affect the firm's going concern audit opinion while the firm growth has no substantial impact on the firm's going concern audit opinion. Simultaneously, financial distress, firm growth, and previous year's opinion significantly affected the firm's going concern opinion.
\end{abstract}

Keywords:

Financial Distress, Firm Growth, Previous Year's Opinion and Going Concern Opinion.

Article Received: 18 October 2020, Revised: 3 November 2020, Accepted: 24 December 2020

\section{Introduction}

Investors have to be selective in making investment decisions because besides being able to provide profits, investment can also provide losses. Based on IDX statistic data 2018, the Composite Stock Price Index (CSPI) decreased by $-2.54 \%$ in 2018. Of the three business sectors, namely the main sector, manufacturing sector, and service sectors listed on the Stock Exchange Indonesia, most decreases in stock prices came from the service sector, which was $-7.91 \%$. This decrease became an alarm for investors to be more selective in making investment decisions.

Before investing, investors must analyse in advance the feasibility of their investment plans to avoid future losses. One of the investors' considerations in making investment decisions is the financial statements and the opinion of the auditor regarding financial statement of the firm.
One of the basic assumptions for financial statements preparation and presentation is going concern basis where the entity will continue in the future its business. Going concern of the company is important for interested parties, especially for investors. Although the audit does not aim to evaluate the company's financial condition, the auditor has the responsibility based on the audit standard to assess the company's going concern (Arens et al., 2017:56).

The auditor has the responsibility to obtain appropriate and sufficient audit evidence in terms of the accuracy of going concern assumptions used by management in financial statement preparation and presentation and to determine whether there is a material lack of certainty about the entity's capacity to sustain its business. If the auditor has substantial doubts about the going concern of a firm, then under Auditing Standard 570 , it is required that the auditor expressed his 
doubts in opinion paragraph. In this study, we call it a going-concern audit opinion. This can be formed in a paragraph of unqualified opinion with emphasis of matter, qualified opinion, adverse opinions, or disclaimer opinion.

Financial condition is one of the things that concern the auditor in assessing the going concern of the company. Financial difficulties (financial distress) experienced by the company certainly need to be questioned about its ability to maintain the going concern. Financial distress can be measured through bankruptcy prediction models such as Z-Score modification by Altman, Y-Score by Ohlson, X-Score by Zmijewski, G-Score by Grover, and S -Score by Springate. Based on the initial survey conducted by the researchers, the study of the effect of financial affliction on the concerned impression of audit opinion of companies has been carried out, but almost all of these studies used the Z-Score bankruptcy prediction model by Altman. No one has ever used the G-Score model as an indicator of measurement. We decided to use this model because based on the research conducted by Pakdaman (2018) in a journal published by Revista Espacios, the prediction of bankruptcy with the G-Score model by Grover had a higher degree of accuracy compared to other prediction models, including the Z-model score by Altman. The same thing was stated in the research conducted by Lupia (2001) Prihantini and Sari (2013); Fauzan and Sutiono (2017); Farhana et al. (2017).

The going concern of a firm also can be discerned from the growth of the firm. Company that experience growth is considered to indicate that the company is able to keep its business properly so that they can maintain its going concern. Company growth can be measured by several indicators, including sales growth, EAT (earnings after tax) growth, EPS (earnings per share) growth, or DPS (dividend per share) growth. Based on the results of the researchers' initial survey, almost all of the study of the company growth's impact on the affirmation of firm's going concern audit opinion utilized sales improvement as an indicator of the firm's growth. It makes the researchers want to use another indicator to measure the growth of the company, namely the growth of EAT (earnings after tax) and find the association with the going concern opinion given by the auditor. The selection of this indicator is based on the description in Utari et al. (2014: 68) stated that from various types of growth indicators, the most important is EAT growth because EAT growth determines EPS and DPS growth. Growth is the hope for shareholders or company owners. In addition, there are different research results in the study of the company growth's impact on the company's going concern opinion. Research by Ginting and Suryana (2014); Nugroho et al. (2018) found that the growth of the firm has influenced the affirmation of opinion on going-concern issues. This research is different from the results conducted by Rakatenda and Putra (2016); Myers et al. (2018) Mukhtaruddin et al. (2018); which asserted that the affirmation of going-concern audit opinion is not affected by the growth of the firm.

Alongside financial strain and company growth, the audit opinion of previous year also impacted the opinion on going concern issues. The reason is due to the performance of a firm in the current year is inseparable from the conditions that occurred in the previous year. In addition, going concern audit opinion is bad news for investors because this opinion contains information that the company is facing difficulties. It makes investors tend to react negatively by withdrawing funds or investments from companies and creditors will be more stringent in providing loans (Menon and Williams, 2010). If this happens, the company will get worse and worse. Nevertheless, there are different results on studies about the impact of the previous year's audit opinion regarding going concern opinion by the auditor. Research conducted by Trenggono and Triani (2015); Ittonen et al. (2017) states the going concern opinion by the auditor was affected significantly by. This foundings of this study are in line with research conducted by Khaddafi 
(2015) but different from the research conducted by Rakatenda and Putra (2016) which states that the going concern opinion given by the auditor was not affected by the previous year's audit opinion.

\section{Literature Review}

\section{Agency Theory}

Agency relationships was defined by Jensen and Meckling (1976) as contracts where one or more people (principals) ask the other party (agent) to carry out some jobs on behalf of the principal and then delegate the authority of making decisions to the agent. In a company, the principal is the shareholders and those who act as agents are the management.

Messier et al. (2017: 6) states that there is two problems resulted by this agency relationship, namely information asymmetry and conflict of interest due to dissimilarity of purpose. Management (agent) has an obligation to prepare and report financial statements as a form of accountability to the principal. However, the absence of the principal to observe the process directly made management in a position to manipulate the report. These problems cause the demand for auditing arises. Auditors have to assess the financial statements' fairness and publishing an independent auditor's report that will be used by stakeholders to make business decisions.

\section{Signaling Theory}

Spence (1973) states that said that the sender (owner of the information) tries to provide relevant information that could be useful for the recipient. The recipient will then adjust his actions according to the signal received.

According to Godfrey at al. (2010: 375), companies use the accounts in financial statements to signal expectations and intentions regarding the future. Manager would try to signal that to the investor via the accounts if they expected a high level of future growth by the firm. If the firm has bad news, the managers would have incentives not to report. However, to maintain credibility in effective markets where their shares are traded, they would also have the incentive to report their bad news.

\section{Going Concern Assumption dan Going Concern Audit Opinion}

One of the basic assumptions in the financial statements ' preparation and presentation is going concern assumption. It is states in The Auditing Standard that the auditor has the responsibility to obtain sufficient and relevant audit proof about the accuracy of the assumptions of concerns by management in the financial statements preparation and presentation and to conclude whether a substantial doubt about the ability of the entitiy to maintain its going concern is identified. If the auditor does not have any doubt about the going concern of the company, then the auditor could give an unqualified opinion.

If it is concluded that there is a considerable uncertainty about the company's going concern then the auditor have to determine whether the financial statements explain adequately the main events or conditions that can cause doubts about the entity's going concern. If the disclosures included in the financial statements are adequate, the auditor must declare an opinion without modification and include an emphasis of matter paragraph in the auditor's report. However, if adequate disclosures are not included in the financial statements, the auditor must state qualified opinion or adverse opinion, in accordance with the conditions, based on SA 705 (Modified Opinion in the Independent Auditor's Report). Under certain conditions, the auditor can believe that it is necessary to ask the management to make or expand its assessment. If management is not willing to do it, the auditor can state a qualified or disclaimer opinion, because the auditor does not obtain sufficient and appropriate evidence regarding the use of company's going concern assumption in financial statements (SA 570 paragraph A27).

\section{Financial Distress}


Manousaridis (2017:9) defines a condition in which a company cannot settle or experience difficulties in paying its debts to creditors as a financial stress. According to Brealey at al. (2017:467) financial distress is one of the causes of company bankruptcy. In addition to financial distress, company bankruptcy can also occur due to other events such as natural disasters, changes in government regulations, and the consequences of legal decisions (Platt and Platt, 2006). In most cases, bankruptcy occurs after financial distress, but not all companies go bankrupt after experiencing financial distress. Based on research conducted by Rezende et al. (2016), 96\% of companies that went bankrupt, experienced financial distress before. Therefore, financial distress and bankruptcy have a very close relationship. One of the bankruptcy prediction models is the G-score model developed by Grover. The Grover model was created by Jeffrey $S$. Grover by redesigning the Altman Z-Score model with the following formula.

$$
G=1,650 X_{1}+3,404 X_{2}-0,016 X_{3}+0,057
$$

$\mathrm{X}_{1}=$ Working capital/total assets

$\mathrm{X}_{2} \quad=$ EBIT/total assets

$\mathrm{X}_{3} \quad=\mathrm{NI} /$ total assets

The categorization of bankcruptcy based on the Grover model is as follow: If the G-score is less than or equal to -0.02 ( $\mathrm{G} \leq-0.02)$, the company is in a state of bankcruptcy. If $\mathrm{G} \geq 0.01$, the company can be categorized in a healthy condition. Meanwhile, if $-0.02 \leq \mathrm{G} \leq 0.01$, the company is categorized in the grey area category.

\section{Firm Growth}

The company's positive growth indicates its ability to maintain its going concern. One indicator of company growth is profit growth with the following formula.

$G R O W T H=\frac{E A T_{t}-E A T_{t-1}}{E A T_{t-1}}$

$$
\begin{array}{ll}
\text { EAT } & =\text { Earnings after tax } \\
\mathrm{t} & =\text { Current year } \\
\mathrm{t}-1 & =\text { Previous year }
\end{array}
$$

\section{Previous Year Audit Opinion}

Previous year audit conception is defined as the comment obtained by the company alongside the financial statements of the year before. Two parts can be classified based on this audit opinion: the company accept the going concern opinion or the company does not accept the going concern opinion.

\section{Conceptual Framework and Hypothesis Testing}

In agency theory, to solve the problem of information asymmetry and conflicts of interest between companies (agents) and investors (principals), agents use the services of auditors. The auditor is in charge of evaluating the fairness of the financial statements including assessing the going concern of a company and release an audit outlook on the financial statements to increase its autorativeness. One of the main indicators of auditors in assessing the going concern of a company is the financial condition of the company. Companies that are undergoing financial distress will lead to bankruptcy if they are not immediately corrected. The indication of bankruptcy is a clear indication of doubt about the going concern of a business entity. The auditor has an obligation to report doubts about the going concern of a company through published audit opinions so that users of financial statements are able to decide on the matter. This makes companies experiencing financial difficulties tend to accede going concern audit opinions from auditors. Research conducted by Mukhtaruddin et al. (2018) shows that financial distress has significantly affected going concern opinion acceptance. The same results were shown in a study conducted by Rakatenda and Putra (2016); Ginting and Suryana (2014); Foster and Shastri (2016).

$\mathbf{H}_{1}$ : There is a significant impact of financial distress to the firm's going concern opinion. 
Signaling theory established that financial statements that provide good news as in profit increase will attract the interest of external parties such as investor, as this case suggests. If investors are interested in investing in the company, it will resulted to a positive effect on the going concern of the firm. Hence, the profit growth of the company would be less likely to be subjected to going concern opinion from the auditor. Conversely, when the financial statements provide bad news in the form of a decrease in profits, investors will likely react negatively by withdrawing their investment and potential investors will discourage their intention to invest in the company. If this happens, the company's going concern will be threatened so that company that experiences negative growth are proned to obtain going concern opinion from the auditor. Ginting and Suryana (2014) also conducted research and supported this which showed that developing companies had an impact on the undertaking the going concern opinion.

$\mathbf{H}_{2}$ : There is a significant impact of firm broadening to the firm's going concern opinion

In agency theory, the auditor is present as a connector between the interests of the agent and principal. Investors as the principal will be very dependent on the audit report issued by the auditor. The opinion on going concern issues given from the year before by the auditor is bad news for investors. It makes investors tend to withdraw their investment from the company. In addition, the company's performance in the current year is inseparable from the situation that occurred in the previous year. This resulted in companies that presented with notion of goingconcern issues the year before will inclide to acquire going concern conception again in the following year. Research conducted by Trenggono and Triani (2015) shows that the outlook of the year before had a substantial impact on the opinion on the going concern issues of the firm. Similar research results are also stated in research conducted by Khaddafi (2015).
$\mathbf{H}_{3}$ : There is a significant impact between previous year opinion to the firm's going concern opinion.

Investors (principals) will act depending on the signal given by the company (agents) through the information contained in the company's financial statements. In addition, investors also depend on the results of the auditor's assessment in the form of an audit opinion to ensure the truth of the information provided by the company. A signal by the company in the form of financial difficulties that are being experienced by the company and an increase or decrease in the company's growth through its financial statements, as well as opinions given by the auditor become a consideration for investors to continue investing or withdrawing their investment back. The going concern of the company in the future is influenced by the decision of the investors.

$\mathbf{H}_{4}$ : Financial distress, firm growth, and opinion of the year before have a significant impact on the firm's going concern opinion.

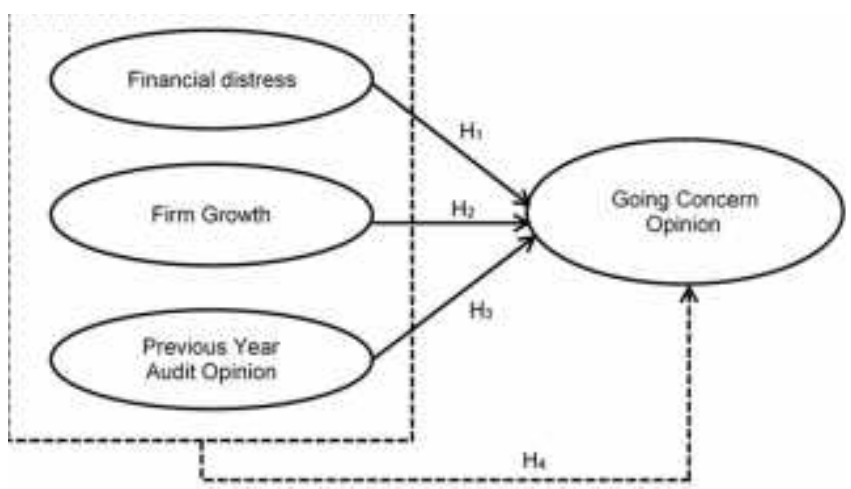

Fig. 1. Conceptual Framework

\section{Research Methodology}

This research is a quantitative study with a correlational study approach using secondary data in the form of financial statements and independent auditor's report of the business organisation. The unit of analysis used in this study is an organization in the form of service sector firms listed on the Indonesia Stock Exchange (IDX). In total, there were 291 service companies listed on the IDX during the 20152017 period. The sample selection was done by 
purposive sampling method. There were 70 companies that complied the sample selection criteria. The observation period in this study was 3 years so that the total sample used was 210 samples. The analysis was performed using logistic regression analysis method with SPSS version 25 software.

\section{Going Concern Opinion Variable}

This research utilized dummy variable to measure going concern opinion. The company that gets going concern opinion was given a value of 1 while those not getting going concern opinion were given 0 .

\section{Financial Distress Variable}

This research measured financial distress by utilizing G-score bankruptcy model by Grover with the formula as follows.

$$
G=1,650 X_{1}+3,404 X_{2}-0,016 X_{3}+0,057
$$

$\mathrm{X}_{1}=$ Working capital/total assets

$\mathrm{X}_{2}=\mathrm{EBIT} /$ total assets

$\mathrm{X}_{3} \quad=\mathrm{NI} /$ total assets

\section{Firm GrowthVariable}

The firm growth variable was measured by earnings after tax (EAT) ratio. If the company has an increase in profits, then the company is experiencing firm growth.

$G R O W T H=\frac{E A T_{t}-E A T_{t-1}}{E A T_{t-1}}$

EAT $=$ Earnings after tax

$\mathrm{t}=$ Current year

$\mathrm{t}-1=$ Previous year
A dummy variable was used to measure the opinion variable of the previous. If in the previous year the auditee received a notion regarding going concern issues, it would be granted a value of 1 . Conversely, in a situation which the auditee did not acquire opinion of the going concern issue the year before, it would be granted a value of 0 .

\subsection{Data Analysis}

This study used logistic regression analysis by SPSS software. The regression equation used in this research is as follows.

$$
\operatorname{logit}(Y)=a+b_{1} \cdot F D+b_{2} \cdot P P+b_{3} . \text { OTS }+e
$$

$$
\begin{array}{ll}
\mathrm{Y} & =\text { Going concern audit opinion } \\
\mathrm{a} & =\text { Constant } \\
\mathrm{FD} & =\text { Financial distress } \\
\mathrm{PP} & =\text { Firm growth } \\
\text { OTS } & =\text { Previous year audit opinion } \\
\mathrm{b}_{1} & =\text { Regression coefficient of FD } \\
\mathrm{b}_{2} & =\text { Regression coefficient of PP } \\
\mathrm{b}_{3} & =\text { Regression coefficient of OTS } \\
\mathrm{e} & =\text { Prediction error }
\end{array}
$$

\section{Result}

\section{Descriptive Statistic}

Based on table 1, it shows that the going concern opinion variable measured using dummy variable, where the firm that receives going concern opinion is coded 1 while those without coded 0 , has a standard deviation of 0.45 and a mean of 0.29 . This means that companies that receive going concern opinion are fewer than firms that do not obtain going concern opinion. Among 210 samples, there were 60 samples that received going concern opinions and 150 samples that did not receive it.

\section{Previous Year Audit Opinion Variable}

Table 1. Descriptive Statistics

\begin{tabular}{crrrrc}
\hline & $\mathrm{N}$ & \multicolumn{1}{c}{ Min } & Max & Mean & $\begin{array}{c}\text { Std. } \\
\text { Deviation }\end{array}$ \\
$\mathrm{Y}$ & 210 & 0 & 1 & 0,29 & 0,45 \\
$\mathrm{FD}$ & 210 & $-41,59$ & 3,25 & $-0,76$ & 4,54 \\
\hline
\end{tabular}




\begin{tabular}{crrrrr}
\hline PP & 210 & 2177,86 & 43,33 & $-19,51$ & 162,71 \\
OTS & 210 & 0 & 1 & 0,24 & 0,43 \\
\hline
\end{tabular}

The financial distress variable measured using G-score has a maximum value of 3.25 and a minimum of -41.59 . The standard deviation is 4.54 while the mean is -0.76 . This shows that most of the companies in the study sample had bad financial condition $(G \leq-0.02)$.

The firm growth variable measured by earning after tax growth indicator has a maximum value at 43.33 and a minimum at -2177.86 . The standard deviation is 162.71 while the mean value is -19.51. It shows that most of the companies in this study experienced a decrease in profits.

Dummy variable was utilized to measure the opinion of previous year, where companies that acquired going concern opinion were coded 1 while those without coded 0 had a standard deviation of 0.43 and a mean value of 0.24 . This indicates the going concern opinion of previous year are less than companies that did not receive going concern in the previous year. Among the 210 samples, 51 received going concern opinion and 159 that did not get going concern opinion in the previous year.

\section{Overall Fit Model Test}

Table 2 shows that the initial $-2 \quad \log$ likelihood value (block number $=0$ ) of 251,424 and the final -2 Log likelihood (block number $=1$ ) of 83,349 . It determine that the addition of the independent variable financial distress, firm growth, and previous audit opinion into the model will decrease the -2 Log likelihood value or the model is better when the independent variables are considered.

Table 2 Overall Fit Model Test

\begin{tabular}{|c|c|c|c|c|c|c|}
\hline \multirow{2}{*}{\multicolumn{2}{|c|}{$\begin{array}{l}\text { Ite } \\
\text { ration }\end{array}$}} & $-2 \log$ & \multicolumn{4}{|c|}{ Coefficient } \\
\hline & & likelihood & Constant & FD & PP & OTS \\
\hline \multirow{3}{*}{$\begin{array}{c}\text { Step } \\
0\end{array}$} & 1 & 251,424 &,- 857 &,- 084 & ,000 & 3,323 \\
\hline & 2 & 251,273 &,- 916 &,- 148 & ,000 & 4,641 \\
\hline & 3 & 251,273 &,- 916 &,- 264 & ,001 & 5,075 \\
\hline \multirow{2}{*}{\multicolumn{2}{|c|}{ Iteration }} & $-2 \log$ & \multicolumn{4}{|c|}{ Coefficient } \\
\hline & & likelihood & Constant & FD & PP & OTS \\
\hline \multirow[t]{8}{*}{ Step1 } & 1 & 111,236 & $-1,726$ &,- 084 & ,000 & 3,323 \\
\hline & 2 & 94,991 & $-2,396$ &,- 148 & ,000 & 4,641 \\
\hline & 3 & 91,672 & $-2,632$ &,- 264 & ,001 & 5,075 \\
\hline & 4 & 84,749 & $-2,591$ &,- 931 & ,002 & 4,775 \\
\hline & 5 & 83,396 & $-2,687$ & $-1,276$ & ,003 & 5,204 \\
\hline & 6 & 83,349 & $-2,716$ & $-1,339$ & ,003 & 5,327 \\
\hline & 7 & 83,349 & $-2,717$ & $-1,342$ & ,003 & 5,333 \\
\hline & 8 & 83,349 & $-2,717$ & $-1,342$ & ,003 & 5,333 \\
\hline
\end{tabular}

\section{Nagelkerke R Square $\left(\mathbf{R}^{\mathbf{2}}\right)$}

Table 3 shows that the Nagelkerke R Square has a value of 0.789 . It signifies the variability of the dependent variable which can be determined by the independent variables in this study is
$78.9 \%$, while the remaining $21.1 \%$ is determined by other variables that do not include in this study.

Table 3 Coefficient of Determination

\begin{tabular}{cccc}
\hline \multirow{2}{*}{ Step } & -2 Log & Cox \& & Nagelkerke \\
& likelihood & Snell R & R Square \\
\hline
\end{tabular}




\begin{tabular}{llcc}
\hline & \multicolumn{3}{c}{ Square } \\
1 & $83,349^{\mathrm{a}}$ &, 551 &, 789 \\
\hline
\end{tabular}

\section{Feasibility of Regression Models Test}

Based on table 4, the test result shows that the value of sig is 0.719 . It means that the value is greater than 0.05 and therefore it can be said that observation value can be predicted by the model.

Table 4 Hosmer and Lemeshow's Goodness of Fit

$$
\text { Test }
$$

\begin{tabular}{cccc}
\hline Step & Chi-square & df & Sig. \\
1 & 5,354 & 8 &, 719 \\
\hline
\end{tabular}

Table 5, shows that there are 150 companies that do not accept going-concern opinions according to predictions, while the result of observations shows that there are 147 companies that do not accept going-concern opinions. Thus, the classification accuracy is $98 \%$. Meanwhile, for companies that received going concern opinion, there are as many as 60 companies according to predictions while in the observation results, only 50 companies received going concern opinion. Thus the level of classification accuracy is $83.3 \%$. From these two things, it can be concluded that the overall classification accuracy is $93.8 \%$.

\section{Classification Matrix}

Table 5. Classification Matrix

\begin{tabular}{llrrrc}
\hline & & \multicolumn{3}{c}{ Predicted } \\
& & & \multicolumn{2}{c}{ Y } & Percentage \\
& Observed & & 0 & 1 & Correct \\
\multirow{3}{*}{ Step 1 } & Y & $\mathbf{0}$ & 147 & 3 & 98,0 \\
& Overall & $\mathbf{1}$ & 10 & 50 & 83,3 \\
& Percentage & & & 93,8 \\
\hline
\end{tabular}

\section{Logistic Regression Analysis}

The logistic regression equation model is formed by looking at the output of variables in the equation (table 6) in column B.

Table 6. Variables in the Equation

\begin{tabular}{llrrrrrr}
\hline & & \multicolumn{1}{c}{ B } & S.E. & Wald & df & Sig. & Exp(B) \\
Step & FD & 1,342 &, 413 & 10,538 & 1 &, 001 &, 261 \\
$1^{\text {a }}$ & PP &,- 003 &, 006 &, 246 & 1 &, 620 & 1,003 \\
& OTS & 5,333 &, 797 & 44,790 & 1 &, 000 & 207,007 \\
& Constant & 2,717 &, 352 & 59,677 & 1 &, 000 &, 066 \\
\hline
\end{tabular}

a. Variable(s) entered on step 1: FD, PP, OTS.

Based on the SPSS output in table 6, the logistic regression equation in this research is as follows.

$$
\begin{aligned}
& \operatorname{logit}(Y)=-2,717-1,342 . F D- \\
& 0,003 . P P+5,333 \text {. OTS }
\end{aligned}
$$

$\mathrm{Y}=$ = Going concern audit opinion

FD $\quad=$ Financial distress

PP = Firm growth

OTS = Previous year audit opinion

\section{Hypothesis Testing Partial Testing}

Hypothesis testing using the Wald test was done by comparing the significance value (sig) in table 6 with the level of error $(\alpha)$ that has been determined. The determination of acceptance or rejection of the hypothesis in this study is based on the significance level $\alpha=5 \%$ or 0.05 . Based on table 6 it can be seen that the first hypothesis $\left(\mathrm{H}_{1}\right)$ 
which affirms that the going concern opinion of the firm is affected by financial distress is accepted because the test results show that the value of sig. amounted to 0.001 which is smaller than $\alpha=0.05$. The second hypothesis $\left(\mathrm{H}_{2}\right)$ which affirms that the going concern opinion of the firm is affected by firm growth is rejected because the test results indicate that the value of sig. amounted to 0.620 which is greater than $\alpha=0.05$. The third hypothesis $\left(\mathrm{H}_{3}\right)$ which states that the opinion of going concern issues of the firm is affected by the previous year's verdict is accepted because the test results show that the value of sig. amounted to 0,000 which is smaller than $\alpha=0.05$.

\section{Simultaneous Testing}

Simultaneous testing was conducted by comparing the significance value (sig) on the Omnibus Test of Model Coefficients output with a predetermined error rate $(\alpha)$. The test result in table 7 shows the value of sig. is 0,000 which is smaller than $\alpha=0.05$. Thus the fourth hypothesis $\left(\mathrm{H}_{4}\right)$ which states that financial distress, firm growth, and previous year opinion together have an impact on the going concern opinion of the firm is accepted.

Table 7. Omnibus Tests of Model Coefficients

\begin{tabular}{llccc}
\hline & & Chi- & & \\
& & square & df & Sig. \\
Step & Step & 167,924 & 3 &, 000 \\
1 & Block & 167,924 & 3 &, 000 \\
& Model & 167,924 & 3 &, 000 \\
\hline
\end{tabular}

\section{Discussion}

\section{The Effect of Financial Distress on the Firm's Going Concern Opinion}

The result of hypothesis testing shows that financial strain has an impact on the firm's going concern opinion. One of the main indicators for auditors to assess the company's going concern is the company's financial condition. Financial distress experienced by the companies will lead them to bankruptcy if they are not immediately corrected. The indication of bankruptcy is clearly indicating a substantial doubt regarding the ability of the entity to preserve its going concern.

Auditors who are a connector between the interests of agents and principals have an obligation to report hesitates about the going concern of business organisation through published audit opinion so that the principals as users of financial statements can form the correct decisions. Auditors tend to provide going-concern opinions on companies experiencing financial strain.

The results of this research are in line with previous studies conducted by Rakatenda and Putra (2016); Ginting and Suryana (2014) but it is different from research conducted by Trenggono and Triani (2015) which stated that going concern opinion of the business organisation is affected by financial distress.

\section{The Effect of Firm Growth on the Firm's Going Concern Opinion}

The result of hypothesis testing demonstrates that the firm's going concern opinion is not affected by firm growth. Companies that experience a decrease in profits in the current period do not merely acquire an opinion of going concern issues directly from the auditor. The reason is even though the company experienced a decrease in profits that year, it is not certain that the company directly experienced problems regarding its going concern as long as the company still had positive profits and the reasons for the decline in profits could be explained reasonably. In addition, if the company do some big investment like purchase some fixed assets in the current year, the net profit in the current year could be decreased due to an increase in depreciation expense.

Conversely, companies that experience an increase in profits may not be free from the threat of going concern. Companies that have increased profits in the current year but are still in the form of negative profits or who have been in the form of positive profits, but the balance of equity in the balance sheet is still a deficit, are still doubt about its ability to maintain its future going concern. 
This makes companies that experience an increase in profits may still obtain a going concern opinion and the auditor cannot make the firm's growth in the form of earning after tax growth as an indicator in providing going concern opinion.

This research findings are aligned with previous studies conducted by Mukhtaruddin et al. (2018); Rakatenda and Putra (2016) that the firm growth has no impact on the firm's going concern opinion. Nevertheless, it is different from the study conducted by Ginting and Suryana (2014) which showed that firm growth has an impact on the firm's going concern opinion.

\section{The Effect of Previous Year Opinion on The Firm's Going Concern Opinion}

The test on the hypothesis indicates that the opinion of the going concern issues of the firm is influenced by the opinion of the previous year. In the agency theory, auditing is demanded to fix the contractual relationships between agent and principal. Investors as the principal will act depending on the audit report issued by the auditor. The going concern audit opinion given in the previous year by the auditor is bad news for investors. It makes investors tend to withdraw their investment from the company. In addition, the company's performance in the current year is inseparable from the situation that occurred in the previous year. It makes companies that in the previous year received going concern opinion will tend to receive it again in the following year unless the company succeeds in taking actions that are able to free it from its going concern problems.

This research findings are aligned with previous studies conducted by Trenggono and Triani (2015); Khaddafi (2015); Primasari (2017) that the previous year opinion affected firm's going concern opinion. Nevertheless, these results differ from the research conducted by Rakatenda and Putra (2016) which stated that opinion of the going concern issues does not affect the going concern opinion of the firm.
The Effect of Financial Distress, Firm Growth, and Previous Year Audit Opinion on the Firm's Going Concern Opinion

The result of hypothesis testing demonstrates that financial distress, firm growth, and previous year opinion simultaneously affected the firm's going concern opinion. Investors (principals) will act depending on the signal given by the company (agents) through the information contained in the company's financial statements. In addition, investors also depend on the results of the auditor's assessment in the form of audit opinion to ensure the truth of the information provided by the company. The signal given by the company in the form of financial difficulties that are being experienced by the company and an increase or decrease in the company's growth through its financial statements, as well as opinions given by the auditor become a consideration for investors to continue investing or withdrawing their investment back.

If the company's financial statements indicate financial difficulties, decrease in profits and the previous audit report contains going concern opinion, then potential investors will be reluctant to invest in the company and old investors will likely withdraw their investments to prevent greater losses in the future. This investor decision certainly has an impact on doubts about the company's going concern in the future so that financial distress, firm growth, and previous year audit opinion affected on the going concern opinion of the company simultaneously.

\section{Conclusion and Suggestion}

This study concluded that the going concern opinion of the firms is affected by financial distress as well as the audit opinion of the previous year. Meanwhile, the growth of the company has no substantial impact on the going concern opinion of the firm. Simultaneously, financial distress, firm growth, and previous year's opinion have a substantial impact on the firm's going concern opinion.

There are also several limitations in this study such as the coefficient of determination $\left(R^{2}\right)$ in 
this study is only 0.789 . This means that the dependent variable's variability in this study determined by the independent variable is $78.9 \%$ while the remaining $21.1 \%$ is determined by other variables not included in this study. So, we recommend to add other independent variables for future research. Moreover, the object in this study only focuses on service sector companies listed on the IDX. So, we recommend adding another sector company for future research.

\section{References}

Arens, A. A., Elder, R. J., Beasley, M. S. and Hogan, C. E. 2017. Auditing and Assurance Services: An Integrated Approach. Sixteenth Edition. USA: Pearson Education.

Brealey, R. A., Myers, S. C. and Allen, F. 2017. Principles of Corporate Finance. Twelfth Edition. USA: McGraw-Hill Education.

Farhana, I., Rahmawaty and Basri, H. 2017. The Determinants of Going Concern Audit Opinion (An Empirical Study on Non-Bank Financial Institutions Listed in Indonesian Stock Exchange 2008-2014). Journal of Accounting, Finance and Auditing Studies. 3(4): 32-51.

Fauzan, H. and Sutiono, F. 2017. Perbandingan Model Altman Z-Score, Zmijewski, Springate dan Grover dalam Memprediksi Kebangkrutan Perusahaan Perbankan (Studi Kasus pada BEI Tahun 2011-2015). Jurnal Online Insan Akuntan. 2(1): 49-60.

Foster, B. P. and Shastri, T. 2016. Determinant of Going Concern Opinions and Audit Fees for Development Stage Enterprises. In $\mathrm{R}$. Graham (Ed.), Advances in Accounting Vol. 33 (pp. 68-84). USA: Elsevier.

Ginting, S. and Suryana L. 2014. Analisis Faktorfaktor yang Memengaruhi Opini Audit Going Concern pada Perusahaan Manufaktur Di Bursa Efek Indonesia. Jurnal Wira Ekonomi Mikrosil. 4(2): 111-120.

Godfrey, A., Hodgson, A., Tarca, A., Hamilton, J. and Holmes, S. 2010. Accounting Theory. Seventh Edition. Australia: John Wiley \& Sons Australia, Ltd.
Ittonen, K., Tronnes, P. C. and Wong, L. 2017. Substantial Doubt and the Entropy of Auditor's Going Concern Modifications. In A.C.S. Cheng (Ed.), Journal of Contemporary Accounting and Economics. Vol. 13 (pp. 134-147). USA: Elsevier.

Jensen, M. C. and Meckling, W. H. 1976. Theory of the Firm: Managerial Behaviour, Agency Costs and Ownership Structure. Journal of Financial Economics. 3: 305-360.

Khaddafi, M. 2015. Effect of Debt Default, Audit Quality and Acceptance of Audit Opinion Going Concern in Manufacturing Company in Indonesia Stock Exchange. International Journal of Academic Research in Accounting, Finance and Management Sciences. 5(1): 80-91.

Lupia, A. 2001. Delegation of Power: Agency Theory. Elsevier. United States. Thesis. Swedia: School of Economics and Management Lund University.

Manousaridis, C.O. 2017. Z-Altman's Model Effectiveness in Bank Failure PredictionThe Case European Banks.

Menon, K. and Williams, D. 2010. Investors Reaction to Going Concern Audit Reports. The Accounting Review. 85(6): 2075-2105.

Messier, W. F., Glover, S. M. and Prawitt, D. F. 2017. Auditing and Assurance Services: A Systematic Approach. Tenth Edition. New York: McGraw-Hill Education.

Mukhtaruddin, Pratama, H. and Meutia, I. 2018. Financial Condition, Growth, Audit Quality and Going Concern Opinion. Journal of Accounting, Business and Finance Research. 2(1): 16-25.

Myers, L.A., Shipman, J. E. and Swanquist, Q.T. 2018. Measuring the Markets Response to Going Concern Modifications: The Importance of Disclosure Timing. Review of Accounting Studies. 23(4): 1512-1542.

Nugroho, L., Nurrohmah, S. and Anasta L. 2018. Faktor-faktor yang Memengaruhi Opini Audit Going Concern. Jurnal Sistem Informasi, Keuangan, Auditing dan Perpajakan. 2(2): 96-111. 
Pakdaman, H. 2018. Investigating the Ability of Altman and Springate and Zmijewski and Grover Bankruptcy Prediction Models in Teheran Stock Exchange. Revista Espacios. 39(14)

Prihantini, N. M and Sari, M. R. 2013. Prediksi Kebangkrutan dengan Model Grover, Altman, Z-Score, Springate dan Zmijewski pada Perusahaan Food and Beverage di Bursa Efek Indonesia. E-Jurnal Akuntansi Universitas Udayana. 5(2): 417-435.

Platt, H. D. and Platt, M.B 2006. Understanding Differences Between Financial Distress and Bankruptcy. Review of Applied Economics. 2(2): 141-157.

Primasari, N. S. 2017. Analisis Altman Z-Score, Grover Score, Springate dan Zmijewski Sebagai Signaling Financial Distress. Accounting and Management Journal. 1(1): 23-43.

Rakatenda, G.N. and Putra, I.W. 2016. Opini Audit Going Concern dan Faktor-faktor yang Memengaruhinya. E-Jurnal Akuntansi Universitas Udayana. 16(2) : 1347-1375

Rezende, F. F., Montezano, R. M., Oliveira, F. N. and Lameira, V. 2017. Predicting Financial Distress in Publicly-Traded Companies. Revista Contabilidade and Financas. 28(75): 390-406.

Spence, M. 1973. Job Market Signaling. Quarterly Journal of Economics. 87(3): 355-374.

Trenggono, L. and Triani, N.A. 2015. Analisis Indikator yang Memengaruhi Auditor dalam Memberikan Opini Going Concern pada Suatu Perusahaan dengan Pendekatan ISA 570. Jurnal Akuntansi Akrual. 6(2): 144165.

Utari, D., Purwanti, A. and Prawironegoro, D. 2014. Manajemen Keuangan. Jakarta: Mitra Wacana Media. 